\section{SOCIAL BIOLOGY IN EDUCATION}

A CONFERENCE on the place of social biology in education was held by the British Social Hygiene Council at Tavistock House, London, W.C.1, on October 24.

Sir Cyril Norwood, giving the presidential address, made no claim to be a biologist, but stated that during his forty years of educational work he had been increasingly impressed by the importance of biology in education. One of the implications of social biology is that sex education should be regarded as a normal part of the school curriculum. Sir Cyril made some chastening remarks about those who see the solution in the making of biology a compulsory subject in the School Certificate, remarking that he has a list of at least fourteen subjects which could make a similar claim. Further, deploring the fact of the ridiculously high standards of the university scholarships examinations and referring to the method of selection of sixth-form biologists, he emphasized that primary school pupils being by far the most numerous, constitute the most important aspect of the problem. New advance after the War will inevitably be a matter of decades, particularly in view of the fact that a hundred thousand extra teachers will have to be found and trained. In this connexion the universities will have to face up to their responsibility in the training of teachers, especially by the provision of general honours courses, including biology and social science with a biological basis.

Later in the morning Mr. W. L. Sumner spoke on "Social Biology Now and in the Future". Referring to the annual decline taking place in the mean national intelligence quotient, he mentioned the need for considering eugenic measures. He pointed out that biologists to-day have sufficient knowledge to enable them to produce a biscuit containing adequate vitamins and minerals to satisfy daily needs, but in this as in other respects it is the economic application of biological knowledge that is faulty. In subsequent discussion Mr. David Jordan pointed out the need for democracy in the functioning of the school. Miss Taylor emphasized the importance of habit formation in the primary school, followed by a well-integrated general science course in post-primary schools. Other speakers referred to the results of the application of biological knowledge in the U.S.S.R. and the need for providing the people of Great Britain with an ideal for which they will feel enthusiasm.

The afternoon session was opened by an address by Sir John Graham-Kerr. He gave an account of the life among the South American Indians of the Gran Chaco. He sketched their system of education, including education through the years of adolescence in preparation for adult life. The alertness which is the constant condition of primitive man contrasts very markedly with the unthinking automatism of the product of modern education. He pointed out that the mere indiscriminate collection of facts is no more science than the heaping up of bricks is architecture, and stressed the importance of intermingling poetry and imagination with the accurate establishment of fact. The muscular performance of a skilled craftsman is just as much a manifestation of 'brain power' as is the production of the most erudite thesis. $\mathrm{He}$ deprecated the common tendency to regard manual work as in some way inferior to mental.

Mrs. E. J. Hatfield opened a diseussion on "Social Biology for Teachers in Training", by stating that German university students in Munich and Nurem- berg before the War of 1914-18 had no eritical faculty whatsoever, and that she does not knew of any educational system better than the English. In making plans for post-war training of teachers much thought must be given to the majority of the profession, namely, those who were trained many years ago. This would involve refresher courses lasting for at least a term, with full salary during attendance, in addition to the shorter refresher courses at frequent intervals. It has been her impression while lecturing that a training college student has, in general, a far greater social sense than the academic graduate teacher in the secondary school. The subject of hygiene in the training college, which is compulsory for all students, should include the fundamentals of biology together with its social implications, and in the universities there should be a social biology course for all graduates who intend to take up teaching.

In the discussion which followed, Miss Warden confessed an inability to understand exactly what is meant by the phrase 'social biology', but made a plea for greater co-operation between the medical and teaching professions, particularly in the provision of specialist knowledge on medicine to teachers and on education to medical people. Later in the afternoon Mr. C. Bibby mentioned that in January the Central Council for Health Education would be publishing the first number of a quarterly journal, Health Education, to meet precisely this need.

The evening session on "Our Responsibility for Human Quality in the Colonial Empire" was opened. by Sir Francis Fremantle, giving population statistics from various countries. He quoted various conditional forecasts of population trends and mentioned that the real cause of the decline in the birth-rate is the decay of moral authority of parents, teachers and religion together with the fundamental economic conditions of acquisitive society. The Maoris were given as an example of recovery after apparently inevitable extinction, and the depopulation of Melanesia as a warning of what can happen when white men interfere with native methods of life.

\section{PLANKTON OF THE NORTH SEA*}

DHYTOPLANKTON of the North Sea is being investigated very thoroughly by examination of the continuous plankton records collected by the Oceanographical Department in the University of Hull. Earlier results were published in the Department's Bulletin in 1940 (for the years 1932-37), and the Diatoms for 1938-39, corresponding to the present part, in 1941. The distribution of the Dinoflagellates and Phæocystis in general provides further evidence of the points made in the preceding diatom paper. A picture has gradually been growing of the distribution of the phytoplankton in the area investigated, at first only in the north, later in the central and southern North Sea. Six extra steamship lines were run monthly: from Hull to Oslo, from Leith to Hamburg, Copenhagen and Lerwick, and from Pentland Firth to Hamburg and Bergen. In addition, records were obtained from the Faeroe Shetland Channel in 1939 , the route crossing the southern entrance to the Faeroe-Shetland Channel

* Phytoplankton of the North Sea, 1938-39. Part II-Dinoflagellates Phrocystis, etc, by C. F. Lucas. The Faeroe-Shetland Channel, 1939, by C. E. Lucas, N. B. Marshall and C. B. Rees. Hull Bulletins of Marine Ecology, edited by A. C. Hardy and C. E. Lucas, Nos. 9 and 10, 2, pp. 47-94. Plates XXXIX-IXII. April, 1942. 8s. 
and stopping some hundred miles past the Faeroe Bank. It is most unfortunate that all these valuable activities have necessarily been stopped by the War.

This later dinoflagellate work differs from the previous reports in dealing to a certain extent with the separate species of Ceratium. Ceratium fusus is the most important of these, is usually much the most numerous and tends to determine the apparent distribution of the genus. At times it forms almost 'pure' communities. Increase in Dinoflagellates always follows that of the Diatoms. Phæocystis is usually abundant when there are fewer Diatoms and Dinoflagellates. The importance of 'patchiness' in all three groups is emphasized and also the rapid numerical change in relatively short time and space intervals. In the southern area between 1932-37 and 1938-39 it is found that after increasing until 1937 or 1938 , the Diatoms and Dinoflagellates were much scarcer in 1938 and/or 1939, but Phrocystis was scarcer from 1934 until 1937 and increased again during 1938-39. On the whole, the flagellate data provide confirmatory evidence for the cycle of changes since 1932 which were first deduced from the diatom record up to 1937 and 1939, and have already received some confirmation from the zooplankton for the earlier period.

The persistence of the two large areas of dinoflagellate production in the north-west and southeast provides even better evidence than in the Diatoms of the general agreement between the adjacent and intersecting recorder lines.

It is very interesting that there are signs of relationship between the distribution of some of the Dinoflagellates in the north-western area and that of Sagitta elegans elegans, and this seems to point to a possible association between the organisms found in this area and the Atlantic influence that may be extended there. The north-western area corresponds broadly with Russell's (1939) area of "elegans water" and the south-eastern to his area of "coastal water". The distribution shown of the Ceratium species together with the Diatoms may possibly be associated with signs of an increased flow of (possibly phosphate scarce) water into the area from the English Channel after the early months of 1938. More evidence is provided suggesting that the phytoplankton-productive water of the preceding years may have moved out of the area in a northerly or north-easterly direction.

The results of the Faeroe-Shetland Channel line are very suggestive but much more data are required to bring the work into line with the rest. They do, however, provide for the first time a series of continuous records at fairly short intervals from spring to midsummer, and form a basis for future work.

\section{FORTHCOMING EVENTS \\ (Meeting marked with an asterisk is open to the public)} Saturday, November 7

BIochemrosl SocreTy (in the Department of Organic Chemistry, 1mperial College of Science and Technology, South Kensington, London, $5 . W .7$ ), at 11 a.m. : Discussion on "The Theory and Application of Chromatographic Methods to Biological Problems".

\section{Saturday-Sunday, November 7-8}

Assoctation of Special LIBRARIES aND INFORMation BURFAUX (at the Royal Society, Burlington House, Piccadilly, London, W.1). Saturday

At 11 a.m.: Annual General Meeting. At 12 noon: Sir Richard Gregory, Bart, F.R.S.: "International Systems and Standards" Sunday

At 10.30 a.m. : Symposium on Microfilm.
Monday, November 9

FArmers' CudB (at the Royal Empire Soctety, Craven Street, London, W.0.2), at 2.30 p.m.-Dr. H. T. Moore: "The Cropping Problem of "To-day".

ROYAL GEOGRAPHIOAL SOOLETY (at Kensington Gore, London, S.W.7), at 5 p.m.-Capt. R. C. Farrow : "Forecasting Run-oft from Snow Surfaces".

\section{Tuesday, November 10}

ROYAL INSTITUTTON (at 21 Albemarle Street, London, W.1), at 3 p.m.- Sir James Jeans, O.M., F.R.S. : "Evolution in Astronomy", 2." ASSOCIATION OF SolvNimio WoRkERs (at the Royal Photographic Society, 16 Princes Gate, South Kensington, London, S.W.7), at of "Photography in Science and Industry".

Wednesday, November 11

ROYAL Socterty OF ARTs (at John Adam Street, Adelphi, London, W.C.2), at 1.45 p.m.-Prof. A. W. Ashby: 'Agriculture To-day and To-morrow", 1 : "Efficlency and Output in Agricultural Systems"

Thursday, November 12

INstrTute of Futh (at the Connaught Rooms, Great Queen Street, London, W.C.2), at 2.30 p.m.-Dr. G. E. Foxwell: "The Provision of Smokeless Fuel for Post-War Reconstruction".

PHARMACEUTIOAL SOCIETY (at Friends House, Euston Road, London, N.W.1), at 2.30 p.m.-Prof. J. C. Drummond: "Nutrition".

\section{Friday, November 13}

Assoolation OF SCIENTIFIC WORKERS (at the Royal Photographic Society, 16 Princes Gate, South Kensington, London, S.W.7), at 6.30 p.m. -Dr. H. Mandiwall: "Technical Cinematography in Colour".

Saturday, November 14

Georogtsts' Agsooration (at the Geological Society, Burlington House, Piccadilly, London, W.1), at 2.30 p.m-Mr. C. E. N. Bromehead: "The Early History of Water Supply".

\section{APPOINTMENTS VACANT}

APPICATIONs are invited for the following appointments on or efore the dates mentioned :

Thaoher of General SoIfnck SubJects, and a Teadher of FNGINEERING SUBJECTS-The Principal, Luton Technical College, Luton, Beds. (November 12).

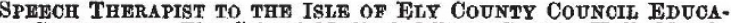
TION CoMmitTEE-The School Medical Officer, County Hall, March, Cambs. (November 12)

Lecturer in Chemistry at the hule Municipal teohnicat Colliege, CHIEFLY FOR INORGaNio ChemISTRY-The Director of Education, Guildhall, Hull (November 16).

HEADMASTER OF THE GULLDFORD JUNIOR TECHNICAL SOHOOLThe Chief Education Officer, County Hall, Kingston-upon-Thames (November 17)

BIOCHEMIST FOR RESEAROH WORK OF NATIONAL IMPORTANOF IN THE DEPARTMENT OF PHYSIOLOGY AND BTOCHEMTSTRY-The Secretary, National Institute for Research in Dairying, Shinfleld, Reading.

IEOTURAR-IN-CHARGE OF CHEMTSTRY-The Principal, Handsworth Technical College, Golds Hill Road, Handsworth, Birmingham 21.

IEOTURER ON WORKS ORGANIZATION AND MANAGEMENT-The Principal, West Ham Municipal College, Romford Road, Stratford, London, E.15.

Assistant Master To thach Sctinch and Mathematios in the JUNIOR TECHNICAY SCHOOY FOR THE BUILDING INDUSTRY-The Director of Education, Education Offlce, South Parade, Nottingham. TWO INSTRTCTORS FOR DAY CLASSES FOR TRAINING OF MARINE ENGTNEERs, at the Stow College, School of Engineering-The Director ENGINEERs, at the Stow College, School of Engineering-The
of Education, 120 Bath Street, Glasgow, C.2 (November 20 ).

GRADUATE WTPH GOOD HONOURS DEGREE, FOR STATISTYCAL RESEAROH-The Secretary, Rothamsted Experimental Station, Harpenden, Herts.

\section{REPORTS and other PUBLICATIONS}

\section{(not included in the monthly Books Supplement) Catalogues}

A Catalogue of Books and Periodicals on Astronomy, Chemistry, Electricity, Engineering, Mathematics, Mining, Navigation, Physics,
etc. (No. 608.) Pp. 32. (London : Bernard Quaritch, Ltd.)

Catalogue of Lewis's Medical and Scientific Lending Library, Supplement 1938-1941. Pp. 168. (London: $\mathbf{H}$. $\mathbf{K}$. Lewis and Co., Ltd.) 48. net (to Subscribers, 2s. net)

Old Science and Medicine, Early Photography, (Catalogue 68.) Pp. 49. (Lundon: E. P. Goldschmidt and Co., Ltd.)

Cambridge Polarograph (Heyrovsky Pattern) for Micro-Analysis. (List No. 109.) Pp. 36. (London : Cambridge Instrument Co., Ltd.) Radiology : the Library of a leading British authority on the subject of Radiology, Röntgenology and kindred Sciences, Pp. 12. (London: The Museum Book Store, Ltd.)

Easy-Flo Silver Brazing Alloy. (Publication 122.) Pp. 4. (London : Johnson, Matthey and Co., Ltd.) 